\title{
ANALIZA PROCEDUR STANÓW AWARYJNYCH SILNIKÓW W SAMOLOTACH LEKKICH I ICH WPLYW NA SKUTKI WYPADKÓW LOTNICZYCH
}

\begin{abstract}
Na podstawie analizy teorii eksploatacji złożonych struktur technicznych przedstawiono samolot lekki jako obiekt eksploatacyjny. Szczególną uwagę zwrócono na zespół napędowy, wskazując na jego istotną rolę w zapewnieniu bezpieczeństwa eksploatacji całego statku powietrznego. Na podstawie analizy instrukcji eksploatacji wybranych samolotów lekkich oraz produkowanych do nich silników dokonano przeglądu procedur postępowania w stanach awaryjnych zespołu napędowego. Następnie wykonano analizę przyczyn wypadków w klasie samolotów lekkich, gdzie wskazano na znaczący udział wypadków spowodowanych awarią zespołu napędowego w ogólnej liczbie wypadków w tej klasie statków powietrznych. Wykonano analizę liczby wypadków ze skutkiem śmiertelnym, wskazując, że awarie zespołu napędowego nie mają w tym względzie znaczącego udziału. Wskazano jednak, że co 12 . wypadek spowodowany awarią tego zespołu pociąga za sobą ofiary śmiertelne. Wyniki analizy wypadkowości samolotów lekkich skonfrontowano z zaleceniami instrukcji dotyczącej postępowania w stanach awaryjnych zespołu napędowego. Posłużyło to do opracowania wniosków na temat aktualnego stanu bezpieczeństwa eksploatacji, jak też zaleceń na przyszłość, w celu podnoszenia niezawodności i bezpieczeństwa eksploatacji samolotów lekkich.
\end{abstract}

Słowa kluczowe: bezpieczeństwo, stany awaryjne silników, niezawodność systemów, procedury awaryjne w lotnictwie

\section{Wprowadzenie}

Współczesne lotnictwo stawia bardzo wysokie wymagania odnośnie do bezpieczeństwa eksploatacji techniki lotniczej [1-4]. Wynika to stąd, że wypadki lotnicze są bardzo często tragiczne w skutkach i powodują śmierć dużej liczby osób podczas pojedynczego zdarzenia, przez co urastają do miana katastrof [4].

\footnotetext{
Autor do korespondencji/corresponding author: Robert Jakubowski, Politechnika Rzeszowska, al. Powstańców Warszawy 8, 35-959 Rzeszów, tel.: (17) 8651466, e-mail: robert.jakubowski@prz.edu.pl
} 
Zapewnienie wysokiego poziomu bezpieczeństwa w lotnictwie odbywa się przez spełnienie stosownych procedur, które dotyczą certyfikacji techniki lotniczej, jak też samego personelu zajmującego się produkcją i eksploatacją. Wiąże się to z właściwie opracowanymi przepisami dotyczącymi technik wytwarzania i eksploatacji techniki lotniczej oraz szkolenia personelu [4]. Rygorystyczne procedury z tego zakresu pozwalają ograniczać do minimum błędy, które moga się przyczynić do zaistnienia okoliczności powodujących obniżenie bezpieczeństwa eksploatacji techniki lotniczej. Jednym ze składników bezpieczeństwa eksploatacji statków powietrznych jest niezawodność systemu eksploatacji, czyli zdolność do realizacji określonych zadań lotniczych w danym czasie i określonych warunkach $[1,4,5]$. Niezawodność jest właściwością statku powietrznego związaną bezpośrednio z jego usterkowością [6]. Z punktu widzenia praktycznej realizacji zadania lotniczego wymaga się takiego przygotowania statku powietrznego, które zakłada pełną (całkowita) niezawodność [4]. Zapewnieniu takiego poziomu niezawodności służy właściwie zorganizowany proces diagnostyki statku powietrznego [7] oraz prognozowanie jego niezawodnej pracy przez ocenę zmiany stanu technicznego jego poszczególnych podsystemów [4, 8, 9]. Analiza procesu eksploatacji urządzeń technicznych [7], w tym także techniki lotniczej [2,3], pokazuje, że mimo ciaggłych wysiłków zmierzających do podnoszenia niezawodności konstrukcji, nie da się uniknąć występowania niesprawności i uszkodzeń [1]. Wskazuje się przy tym, że możliwość wystapienia niesprawności jest tym większa, im większy jest stopień skomplikowania konstrukcji $[4,7,8]$.

Statek powietrzny należy do konstrukcji o stosunkowo dużym stopniu złożoności. Składa się z wielu bardzo różnych funkcjonalnie systemów, które cechują się często bardzo odmiennymi właściwościami z punktu widzenia niezawodności [6, 8]. Równocześnie proces eksploatacji poszczególnych systemów powoduje, że wpływają one mniej lub bardziej na powstawanie uszkodzeń, a przez to na czas niezawodnej pracy. Dotyczy to między innymi sposobów obciążenia konstrukcji, np. elementów silnika, które są poddane obciążeniom mechanicznym i cieplnym, elementów nośnych płatowca, które oprócz obciążeń mechanicznych często są narażone na przypadkowe procesy niekorzystnego oddziaływania warunków atmosferycznych itp. [4]. W całym tym systemie bardzo istotną rolę odgrywa czynnik ludzki - pilot i personel obsługi naziemnej [4, 10-13], których poziom wyszkolenia, a często również inne, bardzo przypadkowe czynniki (np. stan emocjonalny i zdrowotny, stres, poziom zmęczenia) będa powodować nieprzewidywalne oddziaływanie na eksploatowaną technikę lotniczą. Wskazuje się, że w momentach kryzysowych (awaria istotnych elementów samolotów) bardzo ważne są mechaniczne zachowania wyuczone przez personel lotniczy $[10,11]$. Służą temu poprawnie przygotowane procedury postępowania w stanach awaryjnych oraz odpowiedni trening, najczęściej na symulatorach lotu $[4,11]$. 


\section{Niezawodność statku powietrznego}

W pracach $[4,6]$ niezawodność $\mathrm{w}$ odniesieniu do statku powietrznego definiuje się jako prawdopodobieństwo poprawnego działania według zbioru określonych wymagań w zakładanym przedziale czasu, $\mathrm{z}$ uwzględnieniem sumy destrukcyjnych oddziaływań wymuszających uszkodzenia w zakładanych warunkach użytkowania. Można to zapisać zależnością:

$$
R(t)=P\left[U(\tau)_{\{w\}}, 0 \leq \tau \leq t, t\right]
$$

gdzie: $R$ - niezawodność, $t$ - czas, $U$ - zbiór funkcji działań zdefiniowanych dla statku powietrznego, $\{w\}$ - zbiór wymagań, $\tau$-przedział czasu.

Niezawodność może być rozpatrywana jako funkcja intensywności uszkodzeń [6], gdzie przez intensywność uszkodzeń rozumie się względne pogorszenie niezawodności. Wartość tego parametru wyznacza się doświadczalnie, rejestrując liczbę uszkodzeń danego elementu przypadającą na jednostkę czasu eksploatacji. W takim ujęciu niezawodność jest opisywana zależnością:

$$
R(t)=\exp \left[-\int_{0}^{t} \lambda(\tau) \mathrm{d} \tau\right]
$$

gdzie $\lambda$ - intensywność uszkodzeń.

Statek powietrzny jest zespołem składającym się z wielu struktur niezawodnościowych, które determinują jego globalną niezawodność [4, 7]. W klasyczniej budowie statku powietrznego wyróżnia się płatowiec, zespół napędowy, systemy awioniczne i wyposażenie dodatkowe [4]. Każda z tych struktur składa się z mniejszych układów - struktur składowych. W obrębie każdej struktury występują kolejne podstruktury, aż do pojedynczych elementów.

W strukturach niezawodnościowych można odnaleźć elementy, które mają istotny wpływ na proces eksploatacji i determinują zdatność eksploatacyjną statku powietrznego oraz takie, których cechy eksploatacyjne są pomijalne [4]. W wielu przypadkach, tam gdzie jest to możliwe, elementy o krytycznym znaczeniu dla bezpieczeństwa eksploatacyjnego są zwielokrotniane, tworząc tzw. równoległą strukturę niezawodnościową [6], której niezawodność opisuje równanie:

$$
R(t)=1-\prod_{i=1}^{N}\left(1-R_{i}(t)\right)
$$

gdzie: $R$ - niezawodność całej struktury równoległej, $R_{i}$ - niezawodność $i$-tego elementu składowego struktury równoległej, $t$ - czas, $N$ - liczba elementów w strukturze niezawodnościowej. 
Zaletą takiej struktury jest to, że jej niezawodność wzrasta wraz z liczbą elementów, a struktura jest w stanie zdatności eksploatacyjnej, gdy przynajmniej jeden jej element jest w stanie zdatności [6]. Wadą takiego rozwiązania jest wzrost masy, co w lotnictwie ma istotne znaczenie. Dlatego liczba takich struktur jest ograniczana do niezbędnego minimum i dotyczy najistotniejszych elementów statku powietrznego, np. elementów sterowania, które są często dublowane w postaci systemów elektrycznych i hydraulicznych.

Drugą grupę stanowią niezawodnościowe struktury szeregowe. W przeciwieństwie do równoległych cechują się tym, że brak jest elementów rezerwowych, a stan zdatności pojedynczego elementu determinuje zdatność całej struktury [6]. Aby zatem taka struktura była w stanie zdatności, każdy jej element musi być w stanie zdatności. Niezawodność struktury szeregowej opisuje zależność:

$$
R(t)=\prod_{i=1}^{N} R_{i}(t)
$$

Statek powietrzny, jako złożone urządzenie techniczne, jest złożoną strukturą niezawodnościową, w której występują szeregowe i równoległe struktury niezawodnościowe $[4,6]$. Stopień złożoności struktury niezawodnościowej jest efektem poszukiwania racjonalnego kompromisu pomiędzy poziomem niezawodności i bezpieczeństwa eksploatacji a masą i udźwigiem statku powietrznego. W takim układzie najbardziej istotnymi elementami z punktu widzenia niezawodności eksploatacji są te, które cechują się dużym ryzykiem wystapienia uszkodzenia, a ich właściwości eksploatacyjne są istotne z punktu widzenia eksploatacji całego statku powietrznego [4]. Gdy w takiej strukturze występuja układy, które nie są zwielokrotnione, ale są znaczące z punktu widzenia niezawodności całej konstrukcji, to ich wpływ na niezawodność eksploatacyjną statku powietrznego jest znaczący [4].

W klasie samolotów lekkich jedną z kluczowych struktur eksploatacyjnych, determinujących niezawodność całego statku powietrznego jest zespół napędowy. Występuje on pojedynczo, przez co stanowi element struktury szeregowej w niezawodnościowej strukturze samolotu. Ze względu na charakter obciążeń oraz proces zużywania się jego elementów w procesie eksploatacji wykazuje on istotny wzrost podatności na uszkodzenia z czasem jego użytkowania.

\section{Analiza procedur dla stanów awaryjnych zespołu napędowego samolotów lekkich}

Zespołem napędowym w małych samolotach lekkich jest silnik tłokowy ze śmigłem. Ponieważ nie jest to element zwielokrotniony, dlatego jego awaria stanowi istotny problem $\mathrm{w}$ procesie eksploatacji. Uszkodzonego zespołu napędowego nie da się zastąpić innym zespołem, a jego awaria powoduje, że pilot 
w stosunkowo krótkim czasie musi podjąć decyzję odnośnie do kolejnych czynności, które pozwolą uniknąć tragicznego w skutkach wypadku. Procedury postępowania w stanach awaryjnych mają umożliwić pilotowi poprawne działanie, m.in. na wypadek zaistnienia awarii zespołu napędowego. Analiza instrukcji eksploatacji statków powietrznych i silników [14-20] pozwala wyodrębnić działania przewidziane $\mathrm{w}$ stanie bezpośredniej awarii lub wyłączenia silnika oraz w sytuacji, gdy wskazania przyrządów oraz zachowanie silnika sygnalizują możliwość utraty zespołu napędowego w najbliższym czasie.

W instrukcjach eksploatacji samolotów lekkich [14-16] stan wyłączenia silnika jest rozpatrywany $\mathrm{w}$ fazie startu oraz w fazie lotu. W odniesieniu do sytuacji wyłączenia silnika w fazie startu instrukcje podają procedury postępowania dla dwóch przypadków: gdy samolot nie oderwał się jeszcze od pasa startowego oraz gdy samolot jest w fazie wznoszenia po oderwaniu od pasa startowego. W pierwszym przypadku zalecenia dla pilota obejmują dwa możliwe scenariusze, tj. gdy istnieje możliwość bezpiecznego wyhamowania samolotu przed końcem pasa startowego oraz gdy nie ma możliwości bezpiecznego zatrzymania samolotu na pasie. W sytuacji gdy pozostała część pasa jest wystarczająca, zaleca się wykonanie hamowania. Gdy nie ma możliwości wyhamowania przed końcem pasa startowego, należy przygotować samolot do możliwego incydentu W postaci zderzenia z przeszkodą itp. W instrukcji samolotu PIPER PA-28 [16] jest zalecane wykonanie ostrego zakrętu na ziemi, tzw. ,ground loop”. W obydwu przypadkach instrukcja wskazuje na konieczność odcięcia zasilania paliwem silnika, schowania klap, w celu zmniejszenia siły nośnej i zwiększenia efektywności hamowania oraz odłączenia zasilania elektrycznego i iskrowników.

Podczas wyłączenia silnika po oderwaniu się od pasa startowego instrukcje w pierwszej kolejności nakazują przygotowanie statku powietrznego do bezpiecznego lądowania. Pilot musi wybrać najkorzystniejsze miejsce do lądowania w locie bezsilnikowym, przy czym gdy samolot jest na małej wysokości, nie zaleca się wykonywania gwałtownych manewrów, w tym zawracania na lotnisko, gdyż jest to związane z dużą utratą wysokości, co może skutkować niezamierzonym zderzeniem z ziemią przed dotarciem do miejsca lądowania. Następnie, o ile istnieje taka możliwość, pilot powinien podjąć próbę zidentyfikowania przyczyn wyłączenia silnika i w uzasadnionych przypadkach spróbować go uruchomić.

Przerwanie pracy silnika w czasie lotu na dużej wysokości jest najczęściej następstwem przerwania dopływu paliwa lub złego wyregulowania obrotów [14-16]. Procedury awaryjne nakazują pilotowi podobny sposób postępowania jak w przypadku awarii silnika na małej wysokości.

W fazie lotu mogą wystapić znamiona stanu awaryjnego silnika, które nie powodują od razu jego wyłączenia, natomiast niosą ze sobą informacje na temat zbliżającej się awarii tego zespołu. Na samolocie Cessna $150 \mathrm{M}$ instrukcja przewiduje postępowanie na wypadek wystąpienia niewłaściwych wskazań tem- 
peratury i ciśnienia oleju [14]. Wskazania niskiego ciśnienia i wysokiej temperatury oleju sygnalizują zacieranie się silnika. Należy wtedy zmniejszyć otwarcie przepustnicy i przygotować się do lądowania. Należy planować lot w taki sposób, aby możliwa była kontynuacja fazy lądowania nawet przy wyłączonym silniku. Po unieruchomieniu silnika nie należy go ponownie uruchamiać. Instrukcja [14] wskazuje na niejednoznaczność interpretacyjną pewnych symptomów. Przykładowo, gdy ciśnienie oleju jest niskie, a temperatura oleju mieści się w normie, może to oznaczać prawdopodobieństwo uszkodzenia zaworu redukcyjnego ciśnienia zasilania, ale też może być to błąd wskazań przyrządów. Instrukcja w tej sytuacji zaleca przerwanie lotu i rozpoczęcie procedury lądowania w najbliższym możliwym terenie. Podobnie, gdy występuje normalne ciśnienie oleju i wysoka temperatura, może to oznaczać zbyt duże obciążenie silnika w panujących warunkach lotu lub zbyt niski poziom oleju w układzie olejowym. Zaleceniem instrukcji jest zmniejszenie prędkości obrotowej i kontrolowanie temperatury oleju. Jeżeli nie wróci ona do dozwolonego poziomu, należy przerwać lot i przystąpić do lądowania, uwzględniając, że w dalszym czasie może wystapić konieczność realizacji tej fazy lotu z wyłączonym silnikiem.

W przypadku samolotu Piper PA 28-201 Arrow przy wzroście temperatury oleju wskazuje się na konieczność natychmiastowego lądowania w najbliższym możliwym terenie [16]. W instrukcjach silników Rotax [18, 19] przekroczenie temperatury oleju powyżej dopuszczalnej wartości oraz spadek ciśnienia poniżej minimum jest sygnałem do zredukowania mocy silnika oraz wykonania zapobiegawczego lądowania. Przekroczenie temperatury oleju powinno zostać wpisane do książki silnikowej. Zbyt wysoka temperatura głowic cylindra według instrukcji silnika Continental O-200-A [17] jest spowodowana niewłaściwym chłodzeniem. Zalecenia w tym względzie dotyczą lepszego dopasowania składu mieszanki do mocy silnika. Następnie należy otworzyć zasłonki w systemie chłodzącym silnika i ewentualnie zwiększyć prędkość lotu. Gdy wspomniane działania nie spowodują obniżenia temperatury głowic, trzeba zmniejszyć moc i przejść do procedury lądowania. Przed kolejnym startem konieczne jest wyeliminowanie przyczyny zaistniałej niesprawności. W instrukcjach silnika Rotax przy przekroczeniu temperatury głowic zaleca się zmniejszenie mocy do niezbędnego minimum i wykonanie zapobiegawczego lądowania [18, 19].

Nierównomierna praca silnika (spadek prędkości obrotowej, wibracje silnika) może być spowodowana przez oblodzenie, niewłaściwy skład mieszanki, awarię zapłonu lub zacieranie się silnika. Instrukcja silnika Cessna $150 \mathrm{M}$ podaje, że w zależności od domniemanej przyczyny takiego stanu pracy silnika zalecane jest odpowiednie postępowanie. Przykładowo, w przypadku gdy przyczyną niewłaściwej pracy jest oblodzenie gaźnika, należy włączyć jego podgrzewanie. Jeżeli silnik nadal nie może poprawnie pracować, zaleca się zmienić lot do wysokości, gdzie oblodzenie gaźnika nie będzie występować. Gdy oblodzenia nie można zatrzymać, zaleca się przerwać lot i wykonać procedurę lądowania w najbliższym dogodnym miejscu. 


\section{Wypadki lotnicze samolotów lekkich spowodowane awarią zespołu napędowego}

Rejestracją i analizą wypadków lotniczych oraz działalnością na rzecz poprawy bezpieczeństwa lotniczego na terytorium Europy zajmuje się Europejska Agencja Bezpieczeństwa Lotniczego - EASA (European Aviation Safety Agency). Od 2006 roku prowadzi ona rejestrację zdarzeń lotniczych w klasie samolotów lekkich o masie startowej do $2250 \mathrm{~kg}$. Według danych za rok 2012 [3] w okresie od 2007 do 2011 r. średnioroczna liczba wypadków lotniczych dla samolotów lekkich w krajach członkowskich EASA wynosiła 486, a w 2012 r. - 397. Liczba zgonów na pokładzie samolotu, związanych z wypadkami lotniczymi w 2012 r. to 108. Była ona mniejsza o 13 od wartości średniorocznej za lata 2007-2011 (por. tab. 1.). Na podstawie analizy trendu zmian danych zawartych w opracowaniu [3] można stwierdzić, że w przypadku samolotów lekkich od 2006 r. liczba wypadków w państwach członkowskich EASA ciągle się obniża. Przykładowo, w 2006 r. mało miejsce 571 wypadków, w tym 75 ze skutkiem śmiertelnym, a liczba zgonów na pokładzie wyniosła 124 osoby [2].

Tabela 1. Zestawienie liczby wypadków lotniczych w samolotach lekkich w krajach członkowskich EASA (opracowano na podstawie [3])

Table 1. Comparison of the number of aviation accidents for light aircraft in EASA member countries (developed on the basis of [3])

\begin{tabular}{|c|c|c|c|c|}
\hline Lata & Liczba wypadków & Wypadki śmiertelne & Zgony na pokładzie & Zgony na ziemi \\
\hline $\mathbf{2 0 0 7 - 2 0 1 1}$ & $486^{*}$ & $61,8^{*}$ & $121^{*}$ & $1,2^{*}$ \\
\hline $\mathbf{2 0 1 2}$ & 397 & 51 & 108 & 0 \\
\hline
\end{tabular}

* wartość średnioroczna dla danego okresu.

Według zawartego w opracowaniu EASA podziału na przyczyny wypadków lotniczych, zdarzenia spowodowane awarią lub wadliwym działaniem zespołu napędowego plasują się na 5. pozycji pod względem liczby wypadków. Awaria lub wyłączenie zespołu napędowego były przyczyną ok. 600 wypadków samolotów lekkich w okresie 2007-2012 (patrz tab. 2.). Należy zwrócić uwagę, że w tej liczbie było 50 zdarzeń ze skutkiem śmiertelnym. Wskazuje to, że co ok. 12. wypadek spowodowany awarią silnika kończył się ofiarami śmiertelnymi na pokładzie samolotu.

Osobno są analizowane wypadki z przyczyn paliwowych, do których zalicza się m.in: brak paliwa lub jego niewłaściwą jakość, przerwanie dopływu paliwa, oblodzenie gaźnika. Wypadki spowodowane przez te czynniki wiążą się dosyć ściśle z niewłaściwym funkcjonowaniem zespołu napędowego. Włączając tę kategorię do analizy wypadków powstałych z przyczyn zespołu napędowego, uzyskano łączną liczbę wypadków lotniczych w analizowanym okresie wyno- 
szącą 860 , w tym ze skutkiem śmiertelnym ok. 70. Ta grupa przyczyn plasuje się na 3. pozycji w kolejności przyczyn wypadków małych samolotów lekkich.

Tabela 2. Zestawienie liczby wypadków lotniczych samolotów lekkich w okresie 2006-2011 w kolejności przyczyn o największym udziale (opracowano na podstawie [3])

Table 2. Comparison of the number of light aircraft accidents in the period of 2006-2011 in order causes ranked according to the largest share (developed on the basis of [3])

\begin{tabular}{|c|l|c|c|}
\hline Lp. & \multicolumn{1}{|c|}{ Kategoria zdarzenia lotniczego } & $\begin{array}{c}\text { Liczba } \\
\text { wypadków }\end{array}$ & $\begin{array}{c}\text { Liczba wypadków } \\
\text { ze skutkiem śmiertelnym }\end{array}$ \\
\hline 1 & Utrata kontroli podczas lotu & 1200 & 410 \\
\hline 2 & Nieprawidłowy kontakt z drogą startu & 1170 & 15 \\
\hline 3 & Utrata kontroli na ziemi & 630 & 5 \\
\hline 4 & Wyjście poza drogę startowa & 620 & 10 \\
\hline 5 & $\begin{array}{l}\text { Awaria lub wadliwe działanie systemu zwią- } \\
\text { zanego z zespołem napędowym }\end{array}$ & 600 & 50 \\
\hline 6 & $\begin{array}{l}\text { Awaria lub wadliwe działanie systemów nie- } \\
\text { związanych z napędem }\end{array}$ & 540 & 40 \\
\hline 7 & Inne przyczyny niezdefiniowane w wykazie & 420 & 50 \\
\hline 8 & Utrata kontroli podczas lotu & 303 & 119 \\
\hline 9 & Z przyczyn paliwowych & 260 & 20 \\
\hline
\end{tabular}

Przedstawione w tab. 3. zestawienie szereguje wypadki na podstawie udziału liczby wypadków ze skutkiem śmiertelnym w łącznej liczbie wypadków spowodowanych danym czynnikiem. Wskazuje ono, że wypadki lotnicze spowodowane awarią lub niewłaściwym działaniem zespołu napędowego bądź paliwowego plasują się na pozycjach 12. i 13., ze wskaźnikiem poniżej 0,1 . Najgorsze w tym względzie są wypadki spowodowane przez niezamierzony lot $\mathrm{w}$ warunkach meteorologicznych dla lotów według wskazań przyrządów, ogień dym po zderzeniu czy zderzenie z ziemią w locie kontrolowanym, gdzie wskaźnik liczby wypadków z ofiarami śmiertelnymi do ogólnej liczby wypadków dla danego czynnika osiaga poziom powyżej $50 \%$, a w pierwszym z wymienionych przypadków - nawet $80 \%$.

\section{Podsumowanie i wnioski}

Przeprowadzona w pracy analiza wykazała, że silnik wraz z jego wyposażeniem i instalacjami jest kluczowym elementem struktury niezawodnościowej samolotu lekkiego. Jego znaczenie zwiększa fakt, że występuje on jako pojedynczy element $\mathrm{w}$ strukturze niezawodnościowej samolotu. Dlatego istotne jest właściwe przygotowanie procedur postępowania na wypadek jego wyłączenia lub awarii. Analiza wypadków samolotów lekkich wskazuje, że ok. 30\% z nich wynika z uszkodzenia, niewłaściwego działania lub wyłączenia zespołu napędowego lub systemów z nim związanych (układu paliwowego). Natomiast odsetek zdarzeń ze skutkiem śmiertelnym $w$ tej grupie wypadków jest mniejszy niż 
10\%. Zestawienie wskaźnika wypadków ze skutkiem śmiertelnym z łączną liczbą wypadków spowodowanych przez dany czynnik plasuje zespół napędowy w drugiej dziesiątce. Wskazuje to na dużą poprawność procedur postępowania w stanach awaryjnych zespołu napędowego, które wprawdzie nie pozwalają uniknąć wypadku, niemniej łagodzą jego skutki, powodując, że większość z nich kończy się bez ofiar śmiertelnych.

Tabela 3. Zestawienie przyczyn wypadków samolotów lekkich w krajach członkowskich EASA w latach 2006-2011 według największego wskaźnika wypadków śmiertelnych (opracowano na podstawie [3])

Table 3. Summary of light aircraft accidents in EASA member countries in the years 2006-2011 according to the highest rate of fatal accidents (developed on the basis of [3])

\begin{tabular}{|c|l|c|c|c|}
\hline Lp. & \multicolumn{1}{|c|}{ Kategoria zdarzenia lotniczego } & $\begin{array}{c}\text { Wypadki ze } \\
\text { skutkiem śmier- } \\
\text { telnym [WS] }\end{array}$ & $\begin{array}{c}\text { Liczba } \\
\text { wypadków } \\
\text { tącznie [WL] }\end{array}$ & WS/WE \\
\hline 1 & $\begin{array}{l}\text { Niezamierzony lot w warunkach } \\
\text { meteorologicznych dla lotów } \\
\text { wg wskazán przyrządów }\end{array}$ & 40 & 50 & 0,800 \\
\hline 2 & Ogień - dym po zderzeniu & 80 & 130 & 0,615 \\
\hline 3 & $\begin{array}{l}\text { Zderzenie z ziemią w locie } \\
\text { kontrolowanym }\end{array}$ & 60 & 115 & 0,522 \\
\hline 4 & Nieznane lub nieustalone przyczyny & 86 & 187 & 0,460 \\
\hline 5 & $\begin{array}{l}\text { Bliskość w powietrzu, kolizja } \\
\text { w powietrzu }\end{array}$ & 35 & 80 & 0,437 \\
\hline 6 & Operacje na małej wysokości & 119 & 303 & 0,393 \\
\hline 7 & Utrata kontroli podczas lotu & 410 & 1200 & 0,342 \\
\hline 8 & Gwałtowny manewr samolotem & 15 & 75 & 0,200 \\
\hline 9 & Napotkanie turbulencji & 15 & 118 & 0,127 \\
\hline 10 & Inne niezdefiniowane przyczyny & 50 & 420 & 0,120 \\
\hline 11 & $\begin{array}{l}\text { Zderzenie z przeszkodą podczas } \\
\text { startu/lądowania }\end{array}$ & 22 & 183 & 0,120 \\
\hline 12 & $\begin{array}{l}\text { Awaria lub wadliwe działanie systemu } \\
\text { związanego z zespołem napędowym }\end{array}$ & 50 & 600 & 0,083 \\
\hline 13 & Z przyczyn paliwowych & 20 & 260 & 0,077 \\
\hline
\end{tabular}

Przytoczone przykłady postępowania w stanach awaryjnych wybranych samolotów lekkich i stosowanych w nich silników wskazują, że pierwszą czynnością, którą ma wykonać pilot w momencie utraty silnika, jest przejście do optymalnego z punktu widzenia osiagów samolotu lotu bezsilnikowego oraz dokonanie oceny terenu w celu wyboru miejsca do lądowania. Dopiero w kolejnym etapie pilot ma dokonać analizy przyczyn wyłączenia silnika i w uzasadnionych przypadkach podjąć próbę przywrócenia jego pracy. Zawsze, gdy przyczyna wyłączenia silnika nie jest możliwa do ustalenia, pilot musi lądować w najbliższym możliwym terenie. Lot może być kontynuowany dopiero po zweryfikowaniu przyczyn zaistniałej sytuacji i dokonaniu oceny stanu technicznego zespołu napędowego i jego systemów. 
Instrukcje wskazują na pewne symptomy uszkodzeń zespołu napędowego, których pilot nie może jednoznacznie zinterpretować. Podjęte w tym zakresie dalsze działania powinny doprowadzić do wypracowania narzędzi diagnostycznych umożliwiających jednoznaczną ocenę zaistniałej sytuacji awaryjnej. Ułatwi to pilotowi podjęcie właściwej decyzji, szczególnie że w sytuacji awaryjnej racjonalne myślenie ograniczają deficyt czasu, stres i wiele innych czynników.

\section{Literatura}

[1] Cwojdziński L., Żurek J.: Systemy wspierające zarządzanie bezpieczeństwem lotów. Rozwój techniki, technologii i transportu w lotnictwie, Poznań 2012, 19-27.

[2] EASA Annual Safety Review 2007, European Aviation Safety Agency, 2008.

[3] EASA Annual Safety Review 2012, European Aviation Safety Agency, 2013.

[4] Lewitowicz J.: Podstawy eksploatacji statków powietrznych. Statek powietrzny i elementy teorii. Wydawn. ITWL, Warszawa 2001.

[5] Lewitowicz J., Cwojdziński L.: Współczesne statki powietrzne i nowoczesne metody ich eksploatacji. Rozwój techniki, technologii i transportu w lotnictwie, Poznań 2012, 77-89.

[6] Lewitowicz J., Kustroń K.: Podstawy eksploatacji statków powietrznych. Własności i właściwości eksploatacyjne statku powietrznego. Wydawn. ITWL, Warszawa 2003.

[7] Lindstedt P.: Praktyczna diagnostyka maszyn i jej teoretyczne podstawy. Wydawn. ASKON, Warszawa 2002.

[8] Lewitowcz J.: Managment and control of the potential exploitation of fleet aircrafts. Eksploatacja i Niezawodność - Maintenance and Reliability, 37 (2008), 53 56.

[9] Ważny M.: The method of determining the time concerning the operation of a chosen navigation and aiming device in the operation system. Eksploatacja i Niezawodność - Maintenance and Reliability, 38 (2008), 4-11.

[10] Basmadji F., Gruszecki J., Rzucidło P.: Prediction, Analysis and Modeling of Human Performance. SAE Technical Paper, 2009-01-2297, 2009.

[11] Gruszecki J, Rzucidło P.: Simplified Informatics Model of Pilot-Operator and Prediction of Human Performance. AIAA Modeling and Simulation Technologies Conference and Exhibit, Honolulu, Hawaii, AIAA 2008-7110.

[12] Klich E.: Wykorzystanie teorii systemowych w badaniach zdarzeń lotniczych. Rozwój techniki, technologii i transportu w lotnictwie, Poznań 2012, 39-58.

[13] Orkisz M., Kotlarz W., Rypulak A., Turbak W.: The influence of the air-experience of pilots on loads spectrum of turbojet-engines under of the realization of air missions, J. KONES, 9 (2002), 231-238.

[14] Instrukcja użytkowania CESSNA 150.

[15] Instrukcja użytkowania w locie Cessna 152.

[16] Instrukcja użytkowania PIPER PA-28-201-PA.

[17] Instrukcja użytkowania silnika lotniczego typu CONTINENTAL serii O-200-A.

[18] Instrukcja użytkowania dla wszystkich silników typu ROTAX 912.

[19] Instrukcja użytkowania dla wszystkich silników typu ROTAX 914.

[20] Reciprocating engine. Trouble shouting guide. Lycoming 2006. 


\title{
ANALYSIS OF LIGHT AIRCRAFT ENGINE EMERGENCY PROCEDURES AND THEIR IMPACT ON THE EFFECTS OF AIRCRAFT ACCIDENT
}

\begin{abstract}
S u m m a r y
Special analysis was done for small aircraft maintenance problems based on the complex structures maintenance theory. In this background the propulsion systems of small aircraft was carefully studied. The important role of this element in safe aircraft operation was studied and discussed. Based on the maintenance instructions of chosen light aircrafts the emergency procedures for engine faults were analyzed. Then the reasons of light aircrafts accidents were studied. A significant proportion of accidents caused by engine fault in the total number of accidents in this aircraft class are indicated. In this way the conclusions about propulsion faults influence on the light aircrafts operability were formulated. Fatal accidents share in total light aircrafts accidents were analyzed too. In this way some conclusions were formulated about emergency procedures for engine faults and their influence on fatal accidents. It is indicated that every twelfth accident is caused by propulsion system fault. Some conclusions were formulated about actual light aircraft maintenance problems connected with propulsion system faults and about future development of piston engine maintenance systems in light aircrafts.
\end{abstract}

Keywords: safety, engines faults, systems reliability, aviation emergency procedures

DOI: $10.7862 / \mathrm{rm} .2014 .56$

Otrzymano/received: $10.08 .2014 \mathrm{r}$.

Zaakceptowano/accepted: 12.11.2014 r. 
